\title{
EVALUATING NEW RADIOCARBON DATES FROM MIDDEN DEPOSITS NEAR MORIORI TREE CARVINGS, RĒKOHU (CHATHAM ISLAND)
}

\author{
IAN BARBER and JUSTIN MAXWELL \\ University of Otago
}

The Polynesian Moriori of the offshore New Zealand Chatham Islands are associated with a novel carving expression that is unlike any artistic tradition recorded for the indigenous peoples of Oceania. Moriori people indented living karaka (Māori) or kōpī (Moriori) trees (Corynocarpus laevigatus) with human and animal forms before the arrival of New Zealand Māori colonists in 1835 (Barber and Maxwell 2011, Jefferson 1956, King 1989, Richards 2007, Simmons 1980). These carved trees occur in lowland kōpi forests of Rēkohu (Chatham Island) primarily, the large northern island of the group (Fig. 1).

On current evidence the Chatham Islands were first colonised by 15th century A.D., if not earlier (McFadgen 1994, Wilmshurst et al. 2011). A number of researchers now believe that early Polynesian voyagers transferred New Zealand karaka as a fruiting food source to the cool Chatham Islands where tropical domestic plants would not grow (Barber and Maxwell 2011, Costall et al. 2006, Leach and Stowe 2005). There has been much conjecture over the antiquity and precise historical meaning(s) of carved $k \bar{p} p \bar{i}$ trees and the motivation(s) of the carvers (e.g., Jefferson 1956, Kjellgren 2001, Richards 2007, Skinner 1923: 69-71). At the least, it seems reasonable to assume a developing cultural relationship between the practice of tree carvings and economically valuable $k \bar{o} p \bar{i}$ stands.

Carved kōpi trees are designated rākau momori (lit. 'memorial tree') and valued highly by Moriori descendants today (Maui Solomon, pers. comm. January 2012). For contemporary Moriori, rākau momori trees and places provide a unique link or portal to the ancestral world (Solomon and Forbes 2010: 228 n5). Regrettably, the number of living rākau momori has reduced dramatically as a result of historical land clearance. The removal of buffering vegetation in particular has exposed diminishing koppi stands to devastating winds, leading to the collapse of $k \bar{p} \bar{\imath}$ canopy and the death of mature trees. From a possible pre-1835 total of over a thousand carved trees, it appears that less than 200 räkau momori survive today. The future of the remaining carved trees is uncertain (Barber and Maxwell 2011, Maxwell 2010). 

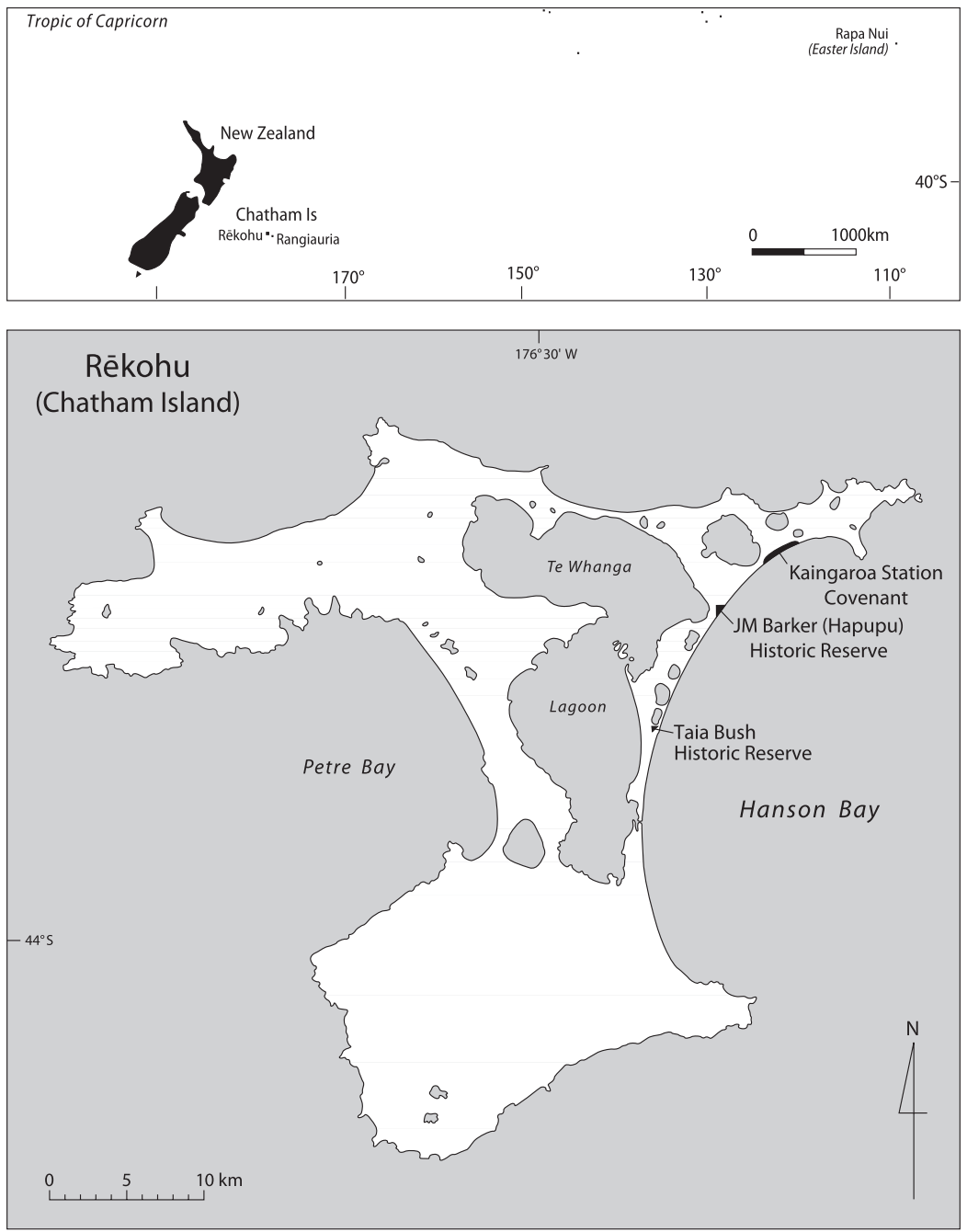

Figure 1. Rēkohu (Chatham Island) showing kōpi stands discussed in text. 
A research project has begun in full partnership with Moriori authority Hokotehi Moriori Trust to assess the prospects for rākau momori conservation. The project is also framed so as to investigate the chronology, historical landscapes and meaning(s) of the carved tree tradition in the Chatham Islands (Barber and Maxwell 2011). This work is intended to contribute to, and support, the development of the Hokotehi cultural database managed by Moriori (Solomon and Forbes 2010). Assessment and recording work has been carried out over three field seasons to meet these ends.

From this work new paired radiocarbon results are available from the archaeological excavation of two small, isolated midden deposits found near or abutting discrete rākau momori associations. Of particular note, one of these dates is a terrestrial age on a carbonised $k \bar{o} p \bar{i}$ seed. We report these dates as the first indications of an archaeological chronology of Moriori engagements with rākau momori stands and landscapes. We also consider whether these ages in site context might represent a terminus ante quem for the rākau momori carving tradition.

\section{BACKGROUND: RATKAU MOMORI ASSOCIATIONS AND DATING ISSUES ON RĒKOHU}

The absolute chronology of räkau momori trees and stands is poorly resolved. In 1928 Skinner reported uncertainty over the age of the carvings, but opined nevertheless: "I do not think that any of the tree trunk figures seen are much older than a century" (Skinner and Baucke 1928: 346). Simmons (1980: 61) reported two radiocarbon dates "less than 200 years old" on unidentified materials from ovens excavated "between two [carving] groves" at Taia. We have also sampled a dead rākau momori trunk core at the J.M. Barker (Hapupu) National Historic Reserve for radiocarbon dating. From the wide calibrated range of this trunk date, we report "an almost $60 \%$ probability that the tree had grown as much as $200 \mathrm{~mm}$ at some point between AD 1650 and 1810" (Barber and Maxwell 2011: 70). However, since this tree "is one of the smaller rakau momori at this locality" (Barber and Maxwell 2011: 71), the antiquity of the national reserve rākau momori tradition is still unclear.

Chronological resolution is complicated further because kōpi stems are characterised by "copious parenchymatous rays" and appear to lack consistent seasonal growth rings (Costall et al. 2006: 11). This proscribes dendrochronology as a reliable dating tool for $k \bar{o} p \bar{i}$ trees. As well, it is not clear when $k \bar{o} p \bar{\imath}$ were first introduced to the Chatham Islands, and therefore, how old any particular $k \bar{o} p \bar{\imath}$ stand might be. Consequently, to investigate the absolute chronology of carved $k \bar{p} \bar{i}$ trees and forest, one is left with the option of resolving datable archaeological site associations and space. ${ }^{1}$ 


\section{Site association}

The association of substantial marine shell midden deposits and carved $k \bar{o} p \bar{\imath}$ stands was first recognised and quantified broadly by Jefferson (1956: 52-57, Appendix B) over the course of several field visits between 1947 and 1953. Jefferson's mid-20th century observations are important as the carved $k \bar{o} p \bar{i}$ "arbours" she recorded then were far more numerous and covered a greater area than today (Barber and Maxwell 2011, Maxwell 2010). In brief summary, Jefferson (1956: 52) recorded 204 "single middens or groups of middens", with "each group or single midden denoting an arbour". Jefferson (1956:52) also identified 119 existing "arbours" with "carvings near them". This last total almost certainly underestimates the number of "arbours" once associated with carvings and middens (see Skinner and Baucke 1928: 345).

At the least, radiocarbon ages from middens associated with $k \bar{o} p \bar{i}$ stands can provide a chronology of Polynesian engagements with the larger koppi resource. Dates from shell midden deposits abutting or near carved trees may be indicative of actual carving ages as well, although this interpretation requires careful spatial recording and evaluation to be plausible. Given the historical loss of carved trees noted above, one must consider that rākau momori clusters identified today may be relics of a more widespread distribution, rather than a primary, discrete relationship. There is also the problem that buried midden sites may not be recognised in many kōpi stands. Thus for 132 "arbour" sites, Jefferson (1956: 52-53) acknowledged that "grass or weed is growing over the middens and it is not possible now to see how many shell-heaps there were".

These problems have been considered in our Rēkohu research. The relative health of all remaining $k \bar{p} p \bar{\imath}$ stands incorporating tree carvings has been assessed in 2010-12 monitoring work with further reference to historical data on canopy health and loss, tree condition and carving resolution. We have also measured kōpi tree size and mapped rākau momori positions in the course of our work, again with reference to earlier data sets where available (Barber and Maxwell 2011, Maxwell 2010). As a result we conclude that discrete räkau momori groups may be interpreted with some confidence as relic cultural patterns where the parent $k \bar{o} p \bar{\imath}$ stands are relatively healthy and intact (see discussion of Kaingaroa Station Covenant distribution below). Midden distribution within $k \bar{o} p \bar{\imath}$ stands is at one level a more difficult pattern to resolve. However, within the two most healthy koppi stands identified in our survey work (Kaingaroa Station Covenant and Taia Bush Historic Reserve), the ground surface is also relatively clear of vegetation, consistent with a pattern identified by Jefferson (1956: 8) for middens in some "arbours". At Kaingaroa in particular, these clear areas have been disturbed extensively 
by animals that have exposed and spread topsoil middens in places. In both of these stands, midden distribution has been tested further by probing. This does not address the possible presence of deep buried middens in these stands. However, at Kaingaroa and Taia at least, our survey records have allowed us to test midden and carved tree associations as discrete social space in a cultural landscape (see Kooyman 2006). Here we have been especially mindful of Jefferson's (1956: 54) observation that "in the larger arbours a smaller shell heap is sometimes to be seen a small distance away from the main group.... In one such case the carvings show a different and less elaborate character... and the off-shoot seems a separate entity".

\section{Radiocarbon dating}

A recent assessment of Polynesian colonisation dates highlights serious inadequacies in the existing archaeological radiocarbon database from the Chatham Islands (Wilmshurst et al. 2011). The identification of appropriate radiocarbon dating materials in stratigraphic context is an important fieldwork priority towards achieving a secure archaeological chronology for Rēkohu.

Short-lived carbonised plant materials such as seeds and twigs are preferred dating materials among standard midden components if they are recovered from secure archaeological contexts. Increasingly New Zealand archaeologists are also dating abundant shellfish from middens where the taxa concerned were sourced from dynamic coastal environments, such as open beaches or shallow inlets in medium to coarse sand with strong tidal flushing. Suspension feeding shellfish from these environments are less likely to have been in contact with older, depleted carbon food sources. The size and abundance of shellfish valves in middens also provides considerable choice and discretion in sample collection (Higham and Jones 2004: 220, Schmidt 2000).

Although marine shell may seem to be "the logical alternative" to charcoal for radiocarbon dating purposes in New Zealand (Petchey et al. 2008: 245), considerable local marine radiocarbon variability (delta R) is reported in a small number of Rēkohu mollusc valves of known age from mid-western and south-eastern locations (see Petchey et al. 2008). If this variance characterises marine waters throughout the Chatham Islands, then shellfish ages from Rēkohu cannot be calibrated with confidence at present. However, our research suggests that the current New Zealand-wide delta $\mathrm{R}$ average advised by University of Waikato Radiocarbon Dating Laboratory $(-7 \pm 45$, F. Petchey, pers. comm. 14 December 2011) is relatively accurate for calibrating radiocarbon dates on suspension feeding tuatua (Paphies subtriangulata) from northeastern Rēkohu archaeological sites as discussed below (see also Barber and Maxwell 2012). 


\section{KAINGAROA STATION COVENANT}

The private, fenced koppi stand at Kaingaroa Station is 247 hectares in area. It lies immediately behind Hanson Bay and is managed and protected under a covenant agreement. Here 22 rākau momori incorporating 24 carvings are distributed over about $2 \mathrm{~km}$ (see Fig. 2). Dead and dying kōpi trees are recorded along the inland margins of the stand. Some trees near the increasingly exposed inland edge are also displaying signs of stress. Within the relatively narrow stand itself, however, mature $k \bar{o} p \bar{i}$ trees are generally healthy and the canopy is continuous, although the future health of the stand is clearly under threat.

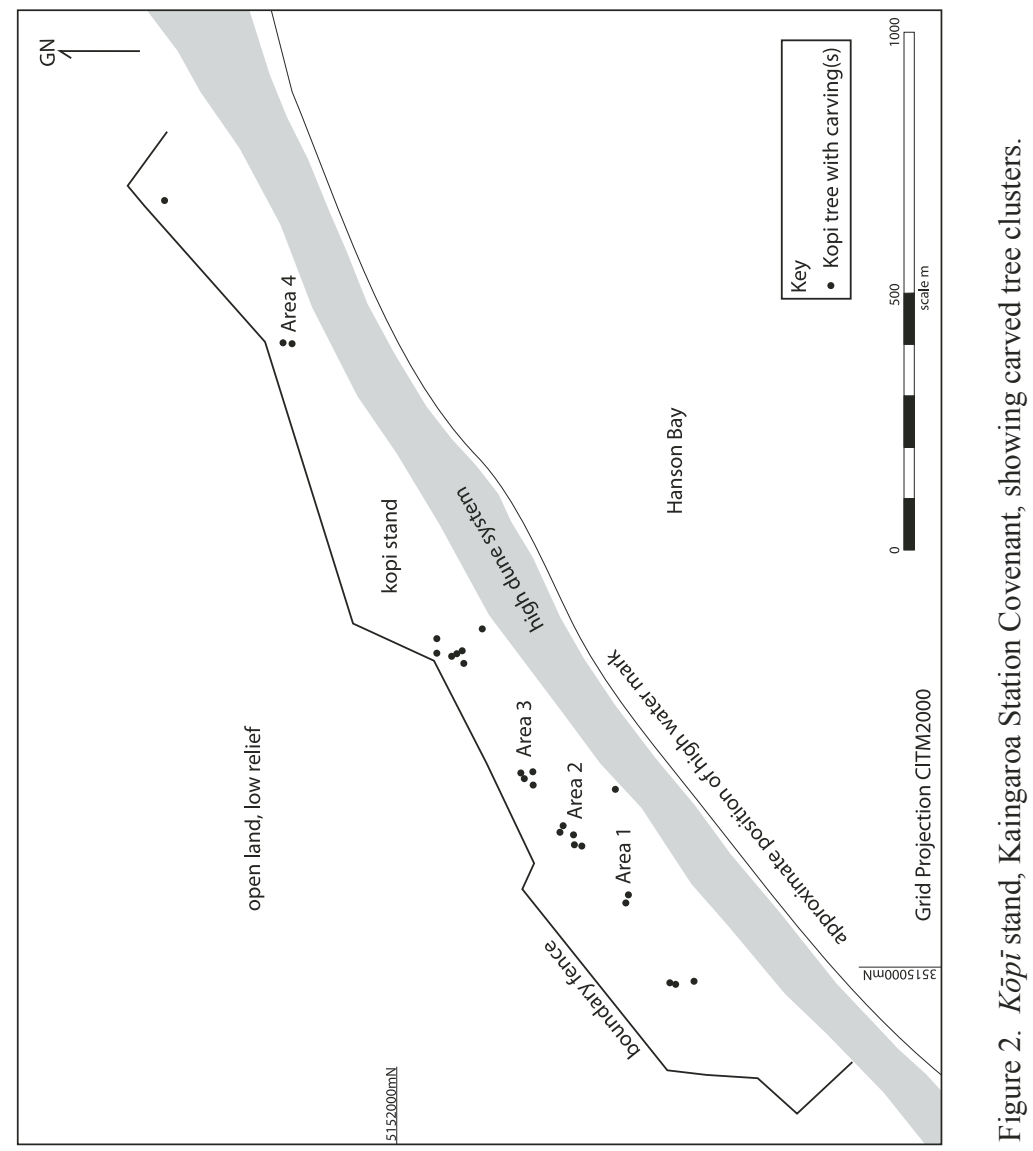


At Kaingaroa, distances of between $80 \mathrm{~m}$ to $250 \mathrm{~m}$ separate discrete groups of 2-5 intervisible rākau momori (Figure 2). While additional carvings were recorded in 2010-2011, these tree numbers and groups are generally consistent with 1990s survey data (Barber and Maxwell 2011). Most of these rākau momori clusters are recorded in a southwest to northeast alignment. Two adjacent trees occur $600 \mathrm{~m}$ north of this alignment. Given the relatively good health of this narrow, remnant $k \bar{p} p \bar{i}$ stand with a range of tree sizes, we interpret the linear arrangement and separation of discrete rākau momori groups here as a cultural pattern.

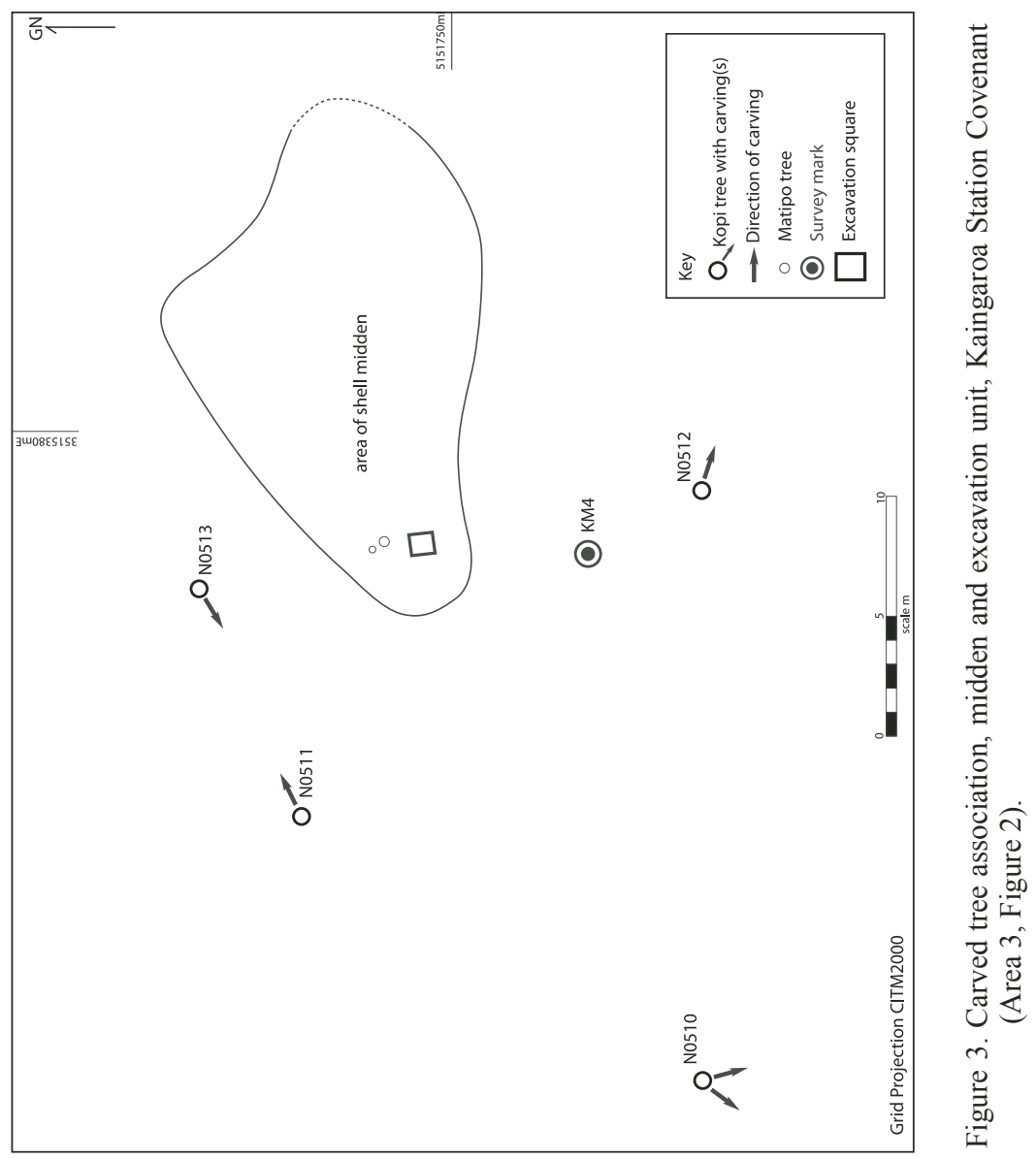


The ground surface over much of the Kaingaroa koppi stand has been disturbed by animals, and is otherwise fairly free of obscuring vegetation other than regenerating $k \overline{o p} \bar{i}$. Consequently, we have mapped midden sites with some assurance here. In this work, shell midden deposits covering hundreds of square metres are often found around or within tens of metres of rākau momori in Areas 1, 2 and 4 (Fig. 2). These deposits may be over 50 $\mathrm{cm}$ deep (Barber and Maxwell 2011). The wide distribution of midden deposits in these areas is such that it is challenging to resolve midden and rākau momori associations there.

Area 3 is unusual in that a single, small, discrete surface midden deposit lies within or about $10 \mathrm{~m}$ distance of three out of four carved trees in this locality (Fig. 3). Less than 30m east of this midden, a further midden deposit of comparable size is recorded. No other midden deposits have been located within $150 \mathrm{~m}$ of the Area 3 carving group. Two of these carved trees are anthropomorphic and face each other (N0511, N0513). N0511 presents a rare, large, symmetrical oval mouth (Fig. 4), while N0513 is relatively faint, with a diamond shape mouth.

N0512 is a long-necked bird in profile. N0510 as an outlier carving in this cluster presents a series of small leaf-like shapes on the trunk and an anthropomorphic figure. Trunk sizes in this group range between N0513 at $29.3 \mathrm{~cm} \mathrm{DBH}$ (diameter at breast height) and N0511 at $58.2 \mathrm{~cm} \mathrm{DBH} .{ }^{2}$ The latter is the largest carved tree recorded in Kaingaroa Station Covenant (Fig. 4).

The western Area 3 midden is exposed within a relatively open area that extends to the south beyond N0512 and to the east below tall koppi canopy. The extent of the midden was confirmed by probing. The deposit is uniformly shallow, with a maximum thickness of about $25 \mathrm{~cm}$. Animals have disturbed and spread much of the upper midden at least, accounting we believe for the eastern extension of the deposit (see Fig. 3). A small, one square metre excavation was opened near two matipo (Myrsine chathamica) trees where it was assumed that the extensive rooting system would have held material in place and discouraged animal disturbance.

The integrity of the dense shell deposit became clear in excavation as numerous nested or articulated bivalves of tuatua in broadly horizontal alignment were recovered below the more broken, disturbed turf sediment ( $5 \mathrm{~cm}$ deep). The midden matrix is black (10YR 2/1) medium grain loamy sand, $22 \mathrm{~cm}$ deep, on very dark gray (7.5YR 3/1) sand. An intact horizon of about $8-16 \mathrm{~cm}$ depth below surface of largely whole and occasionally nested pāua (Haliotis sp.) valves was also identified across the square extending into the sides (Fig. 4). Finfish elements were extremely sparse, and no bird or mammal bone was recovered.

The mix and arrangement of shellfish species at least is notable. Tuatua are soft shore, open beach bivalves while päua are rocky shore univalves (Powell 
1979: 36-37, 416). The dominance of tuatua in the square is consistent both with the proximity of soft shore Hanson Bay, and the components of other midden deposits excavated at Kaingaroa Station Covenant (Barber and Maxwell 2011, 2012). However, while occasional pāua clusters are reported from admittedly limited testing in other larger midden deposits at Kaingaroa Station, nothing like a discrete pāua horizon with numerous whole shells has been identified. The nearest hard shore is several kilometres distant along the northern Rēkohu coastline. ${ }^{3}$ It is reasonable to assume that the pāua were either discarded by a visiting group, or sourced especially from some distance. Some pāua fragments or valves appear to have been cut as well in this midden, suggesting that these shells were sourced with more than subsistence needs in mind.

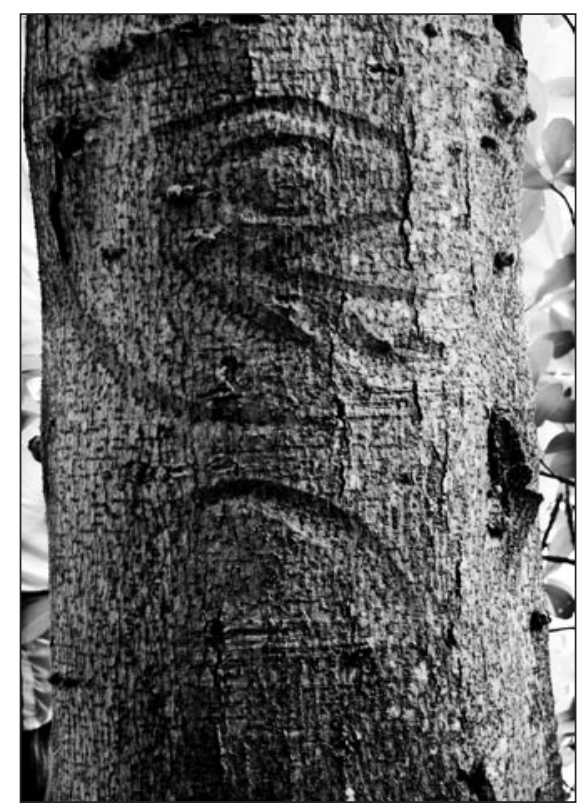

Figure 4. Carved human figure on tree N0511, Kaingaroa Station Covenant, eastern side view. Height from ground level to base of head is $1490 \mathrm{~mm}$. Features in view include a large right eye (width $160 \mathrm{~mm}$ ), a symmetrical oval mouth (width $370 \mathrm{~mm}$ ), a raised right arm and a curved right leg in characteristic crouching position (see Jefferson 1956:25, Richards 2007: 47-48). N0511 is $9 \mathrm{~m}$ west of the dated midden site (Figure 3). Photograph by Justin Maxwell, February 2011. 


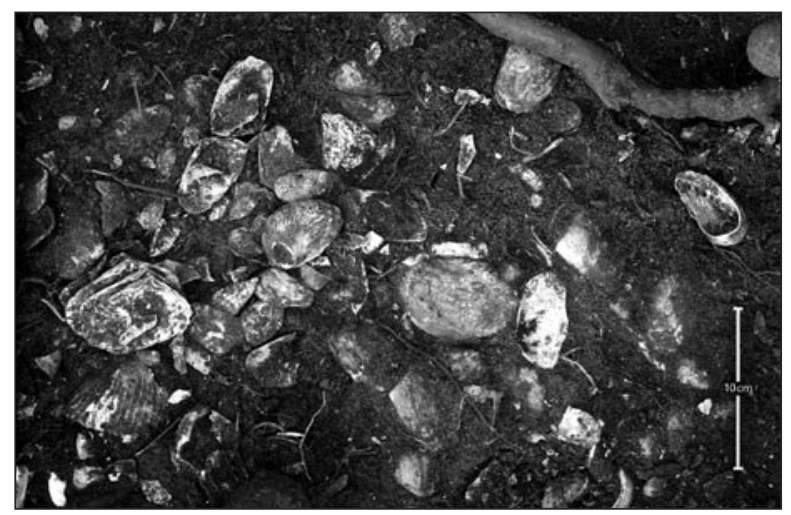

Figure 5. Midden excavation unit associated with Area 3 (cf. Figs 2 and 3), Kaingaroa Station Covenant, showing horizon of päua and nested tuatua below matipo root.

Table 1. Conventional radiocarbon ages before present (CRA BP) and calibrated age ranges $\mathrm{AD}(\mathrm{CAL} A D)$ at 1 -sigma $(p=.68)$ and 2-sigma $(p=.95)$ for radiocarbon dates from Kaingaroa Station Covenant and Taia Bush Historic Reserve sites discussed in text. The marine calibration for Wk- dates is from Reimer et al. 2009 with delta R set at $-7 \pm 45$. Southern Hemisphere atmospheric data for the NZA terrestrial calibration are from McCormac et al. 2004.

\begin{tabular}{|c|c|c|c|c|c|}
\hline SITE/LAB\# & SAMPLE & CRA BP & $\% \delta^{13} \mathrm{C}$ & CAL AD $1 \sigma$ & CAL AD $2 \sigma$ \\
\hline \multicolumn{6}{|l|}{ Kaingaroa } \\
\hline Wk-30903 & tuatua valves & $592 \pm 34$ & $1.8 \pm 0.2$ & $1657-1806$ & $1560-1885$ \\
\hline Wk-30904 & pāua valve & $697 \pm 31$ & $2.4 \pm 0.2$ & $1542-1656$ & $1488-1692$ \\
\hline \multicolumn{6}{|l|}{ Taia } \\
\hline Wk-30906 & tuatua valves & $637 \pm 35$ & $1.4 \pm 0.2$ & $1564-1709$ & $1524-1815$ \\
\hline \multirow[t]{4}{*}{ NZA37128 } & $k \bar{o} p \bar{\imath}$ seed & $236 \pm 15$ & -21.7 & $\begin{array}{l}1661-1673 \\
(15 \%)\end{array}$ & $\begin{array}{l}1652-1675 \\
(24 \%)\end{array}$ \\
\hline & & & & $\begin{array}{l}1744-1758 \\
(17 \%)\end{array}$ & $\begin{array}{l}1738-1798 \\
(71 \%)\end{array}$ \\
\hline & & & & $\begin{array}{l}1762-1771 \\
(10 \%)\end{array}$ & \\
\hline & & & & $\begin{array}{l}1780-1797 \\
(26 \%)\end{array}$ & \\
\hline
\end{tabular}


Two radiocarbon dates from this site were processed on nested, in situ tuatua valves (Wk-30903) and a single intact pāua specimen (Wk-30904), both recovered from the pāua horizon (see Fig. 5). At 1-sigma, these calibrated dates do not overlap (Wk-30904 pāua, AD 1542-1656 and Wk-30903 tuatua, AD 1657-1806), although both indicate a likely, pre-19th century site context. At the 2-sigma distribution, the dates overlap around the later 16th century to 17th century, within the calibrated ranges of 1488-1692 (pāua) and AD 1560-1885 (tuatua) (Table 1). For the tuatua date, the 1835-1885 distribution at least can be discounted given the site context. Until further dates are processed, our inclination is to follow the mid-17th century to 18th century age range for the locally sourced, open beach tuatua, insofar as the two dates diverge at 1-sigma.

\section{TAIA BUSH HISTORIC RESERVE}

The historic reserve at the south end of Lake Taia incorporates a wedge of $k \bar{o} \bar{i}$ "bush" that once extended north to south at least a kilometre and was up to 300m wide (Simmons 1980: 52). Today this köpi reserve covers 1199 hectares. A pine tree (Pinus radiata) stand on the western margin has protected the remnant $k \bar{o} p \bar{i}$ forest from westerly winds for over three decades (Park 1976: 5). Even so, significant carving associations have been lost, presumably before the pine trees provided protection. In the early 1960s Simmons (1980: 52) recorded 140 carvings from three "intact groves" at Taia (Simmons 1965). A single intact association of multiple carved trees ("Taia A" in Simmons 1965) survives today near the southeastern edge of the bush. This association includes 19 carved trees. In the main these carvings are anthropomorphic images. Some include heads alone.

The canopy above the remaining southeastern cluster is currently healthy, while the trees immediately around and including the rākau momori are generally in good condition. Within the cluster there is diversity in tree girth with N0403 at $28.5 \mathrm{~cm} \mathrm{DBH}$ and N0402 at $49 \mathrm{~cm} \mathrm{DBH}$. Healthy trees without carvings extend for tens of metres to the north of this association.

Over an area identified as "Taia South Bush Edge", Jefferson (1956: 66, Appendix B) recorded eight areas of "shell heaps" separated by distances in the range of 90-340 paces. Simmons (1965) mapped two surface "shell scatters" within "Taia A". We have located and mapped the probed area of a single, ground level midden deposit within the remaining "Taia A" rākau momori cluster (Fig. 6). A carved tree is identified on the eastern side of this midden area (N0401, recorded as no. 314 in Simmons 1965: fig. and Plate III). The crouching human figure of N0401 is carved with a prominent headdress, probably a feather kura or awanga that may denote status (Fig. 7, see also Jefferson 1956: 31-32, figs 1-131; Richards 2007 and Simmons 1965: Plates II, III for headdress representations on selected carvings at Taia and 
elsewhere). No other middens or carved trees were identified for well over $100 \mathrm{~m}$ in any direction around this Taia carving association.

The rākau momori associated midden deposit itself shows evidence of deflation and surface disturbance. In general the tuatua valves exposed on the surface are broken. The shell midden is most concentrated and intact where the deposit has been secured around tree roots. Towards the southern margins

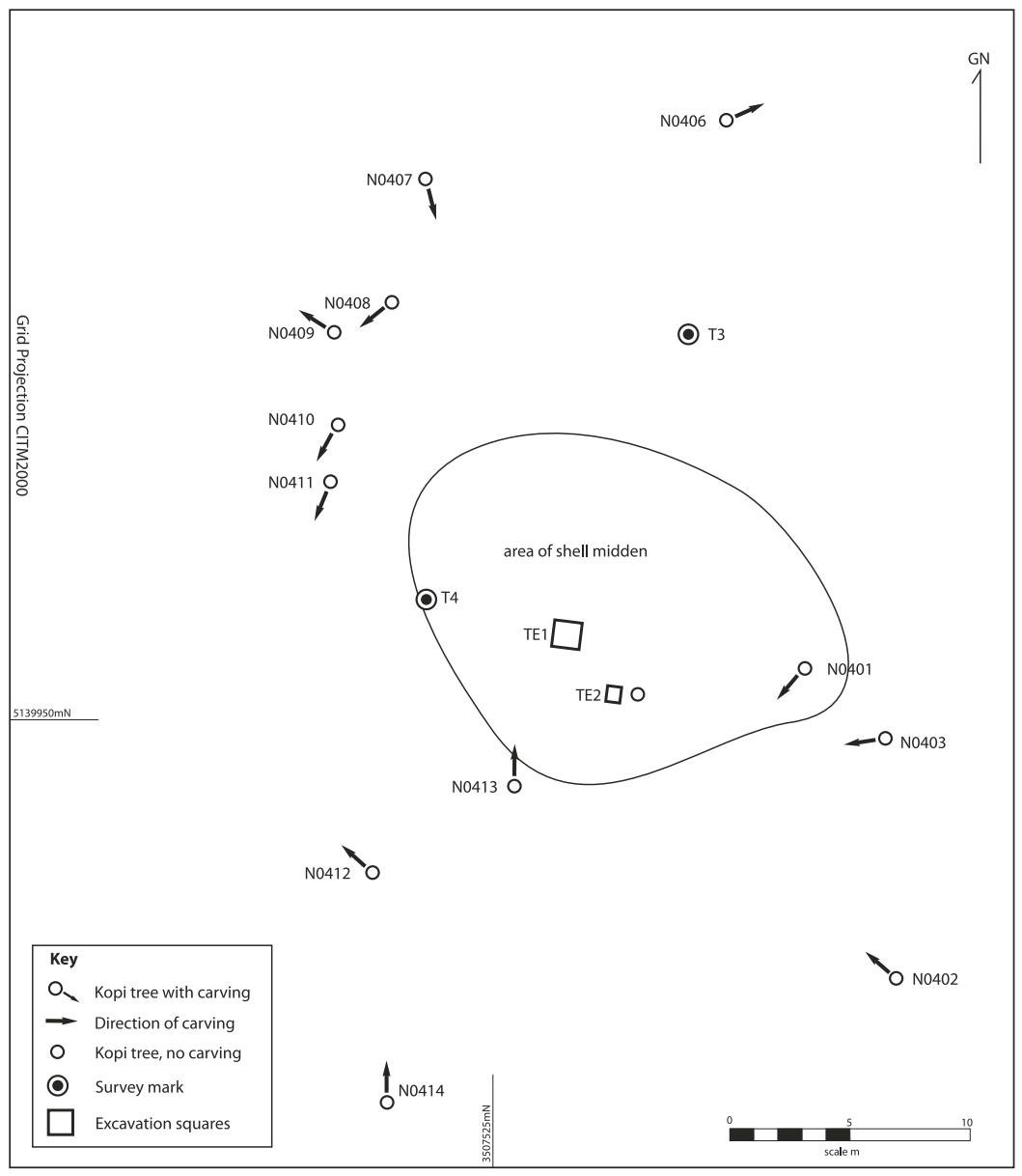

Figure 6. Carved tree association around excavation units and midden, Taia Bush Historic Reserve. 

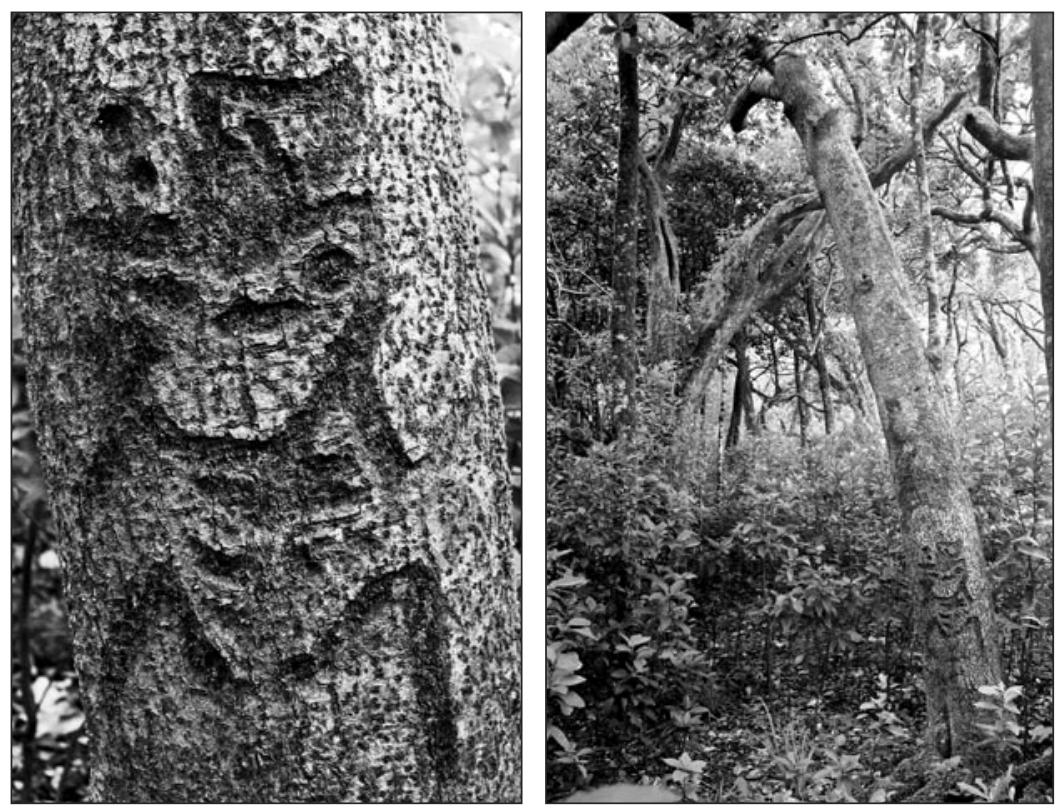

Figure 7. Carved human figure on tree N0401, Taia Bush Historic Reserve, with prominent headdress representation (full headdress height $140 \mathrm{~mm}$, maximum head height only $200 \mathrm{~mm}$ ). Height from ground level to base of crouching figure is $700 \mathrm{~mm}$. N0401 is on the eastern side of the probed and dated Taia midden area. Photographs by Ian Barber, January 2012.

of the midden area an un-carved $k \bar{o} p \bar{i}$ tree with two primary trunks has an extensive root system that is elevated $40-60 \mathrm{~cm}$ vertically above the current surface. Clearly soil if not midden sediments originally covered these roots.

Two excavation units were opened at the southeastern Taia midden. In a $1 \mathrm{~m} \times 1 \mathrm{~m}$ unit the midden deposit (TE1) was relatively shallow $(10-15 \mathrm{cms})$ and confined to the near surface aspect of the black (10YR 2/1) loamy sand topsoil. Tuatua valves were largely broken, other than in the southern corner of the square. Several whale and bird bone fragments were recovered from the midden matrix. The midden sediment in this square appears to have been dispersed, and it is not clear that it is a primary deposit. A further, smaller test unit (TE2: $0.5 \mathrm{~m} \times 0.5 \mathrm{~m}$ ) was also opened at the base of the un-carved tree. Again, the primary tuatua shell component was broken and disturbed near the surface of this unit. However, dense, bedded, intact tuatua specimens, 
including articulated valves, were identified $8-10 \mathrm{~cm}$ below ground surface. In one corner of TE2 the depth of the midden below surface was $21 \mathrm{~cm}$. The basal part of the midden in the unit was characterised by undisturbed, intact sediment. This suggests that the midden was deposited before the rooting system had spread to the excavation area.

Two radiocarbon dates were processed on articulated tuatua valves (Wk30906) and a single carbonised kōpi seed (NZA37128) respectively, both recovered from the lower, intact midden sediment of TE2. The calibrated marine age is AD 1564-1709 at 1-sigma, and 1524-1815 at 2-sigma (Table 1). If this single date is an accurate chronological result, then the age of the midden is most likely pre-19th century. It could be as early as the late 16th century to 17 th century at 1 -sigma. The koppi seed sample has the advantage of no inbuilt age, and an association, obviously, with the local kōpi resource. At 2-sigma, the calibrated range of the koppi date is intercepted between AD $1652-1675$ (24\%) and 1738-1798 (71\%). These intercepts conform closely to the tuatua indications (at 2-sigma) of a 17th century or 18th century chronology at least for this midden.

\section{DISCUSSION}

At present, radiocarbon dates from midden deposits provide the only archaeological means to investigate the chronology of Moriori engagements with räkau momori stands. In reporting four such dates only we acknowledge that more radiocarbon ages on a wider range of marine and (especially) terrestrial materials are needed from these and other sites to fully compare and evaluate radiocarbon results on Rēkohu samples. From the comparison of these dates, however, we note tentatively that tuatua from eastern to northern Hanson Bay may be a relatively reliable marine shellfish for local radiocarbon dating purposes. Elsewhere we report a strong convergence around the mid-16th century through 18th century for calibrated tuatua dates from other midden deposits at Kaingaroa Station Covenant (Barber and Maxwell 2012).

At the very least we observe that these first radiocarbon ages point towards 18 th century and possibly earlier Moriori engagements with kōpi stands in eastern to northern Rēkohu. The presence of a dated carbonised seed at Taia is a further indication that $k \bar{o} p i$ was of local subsistence value when this pre19th century midden was deposited.

At Kaingaroa and Taia, the archaeological landscape indications are that the discrete association of midden deposits and carved trees for the two sites reported here represent non-random, social space. This could mean that Moriori chose to carve mature $k \bar{p} p \bar{\imath}$ trees that had grown up around isolated 
midden deposits. Alternatively, both middens may have been deposited in relation to koppi trees that were being, or had been, carved. The site context suggests to us that the latter explanation is more likely. If social space is marked by the association of midden and carved trees here, it seems more plausible that highly visible rākau momori had primacy as identifiers of spatial significance over small, non-distinctive, ground level midden deposits. There are reasonable grounds, in short, to consider that the midden dates represent a terminus ante quem for the carving tradition at both places.

It is possible that other lost, carved trees in these two places pre-date the rākau momori that are now recorded there. Carvings and midden materials may have been added to each existing association over time as well. At Taia in particular, the relatively wide distribution of carvings that face in different directions could be the result of new rākau momori carvings indented on both bare and previously carved trunks at the location of an existing association (see Fig. 6). And at Kaingaroa, it may be that the single outlier N0510 was added to an existing group, or even marked a general place of (harvest?) importance at which other trees were later carved.

$$
\text { * * * }
$$

These preliminary interpretations will be tested and no doubt refined in further survey, excavation and dating work. At the least, however, the ages reported here begin to define the outlines of a testable, absolute chronology of Moriori engagements with managed rākau momori kōpi forest (see Solomon and Forbes 2010: 223). These results also flag an archaeological challenge to Skinner's earlier 20th century suggestion that none of the carved koppi figures "were much older than a century" (Skinner and Baucke 1928: 346). In that regard, our research aligns with Moriori views of rākau momori as venerable cultural historical expressions of the unique Polynesian society that emerged on Rēkohu (Jefferson 1956: 11-13, Maxwell 2010, Richards 2007, Solomon and Forbes 2010).

\section{ACKNOWLEDGEMENTS}

Hokotehi Moriori Trust as the legal representative of Moriori people is a full partner in the research project reported here. We acknowledge and respect the mana of Hokotehi Moriori Trust over rākau momori sites, knowledge and images. We acknowledge further the support and encouragement of Hokotehi Moriori Trust chair Shirley King, General Manager Maui Solomon, Project Manager Susan Thorpe (formerly Forbes) and Moriori elder Tom Lanauze. We thank the Department of Conservation, especially Richard Nester, for funding radiocarbon dates and processing the required Taia reserve 
sampling permit. Rick McGovern-Wilson, NZ Historic Places Trust, ensured the timely processing of the Historic Places Act archaeological authority (no. 2011/263) required for all of the excavation work. A University of Otago Research Grants funded the 2011 and 2012 fieldwork seasons. Les O'Neill, Department of Anthropology and Archaeology, University of Otago, prepared Figure 1. Susan Thorpe, two anonymous referees and the JPS editor offered helpful comments on earlier drafts of this paper.

\section{NOTES}

1. Khaw (2000) has attempted to age Moriori tree carvings by measuring the fractional, differential growth rate of selected carving edges in relation to a generic $k \overline{o p} \bar{i}$ growth model. We accept that this approach has promise, but believe that some of Khaw's data are too imprecise to allow the method to be applied with any confidence at present.

2. Here it is interesting to compare Jefferson's (1956: 11) observation that only two to six carved trees were found "at any arbour having a midden of only one heap of shells".

3. At Taia, Simmons (1980: 61) also observes that a "local" shell heap section had "paua from the north coast at the base".

\section{REFERENCES}

Barber, I. and J. Maxwell, 2011. A collaborative archaeological research and conservation project for Moriori carved trees (rakau momori), Rekohu (Chatham Island). Archaeology in New Zealand, 54 (1): 62-75.

2012. Archaeological Excavation and Radiocarbon Dating Report for Midden Sites at Kaingaroa Station Covenant and Taia Bush Historic Reserve, Rēkohu (Authority No. 2011/263). Unpublished report to Hokotehi Moriori Trust, Rēkohu, and NZ Historic Places Trust and Department of Conservation, Wellington.

Costall, J.A., R.J. Carter, Y. Shimada, D. Anthony and G.L. Rapson, 2006. The endemic tree Corynocarpus laevigatus (karaka) as a weedy invader in forest remnants of southern North Island, New Zealand. New Zealand Journal of Botany, 44: 5-22.

Higham, T. and M. Jones, 2004. Chronology and settlement. In L. Furey and S. Holdaway (eds), Change Through Time: 50 years of New Zealand Archaeology. New Zealand Archaeological Association Monograph 26, pp. 215-34.

Jefferson, C., 1956. Dendroglyphs of the Chatham Islands: Moriori Designs on Karaka Trees. Wellington: The Polynesian Society.

King, M., 1989. Moriori: A People Rediscovered. Auckland: Penguin Books.

Kjellgren, E., 2001. Art on the edge: The Moriori traditions of Rekohu (the Chatham Islands). In C.M. Stevenson, G. Lee and F.J. Morin (eds), Pacific 2000: Proceedings of the Fifth International Conference on Easter Island and the Pacific. Los Osos, CA: Easter Island Foundation, pp. 281-91. 
Khaw, C.J., 2000. Study of the Chatham Island Dendrography on Karaka Trees. Unpublished BA Hons. Dissertation, Department of Surveying, University of Otago.

Kooyman, B., 2006. Boundary theory as a means to understanding social space in archaeological sites. Journal of Anthropological Archaeology, 25: 424-35.

Leach, H.M. and C. Stowe, 2005. Oceanic arboriculture at the margins. Journal of the Polynesian Society, 114 (1): 7-27.

Maxwell, J., 2010. Conservation of Rakau Momori: An Archaeological Investigation of Historical and Current Management Practices. Unpublished BAHons. dissertation, Department of Anthropology and Archaeology, University of Otago.

McCormac, F.G., A.G. Hogg, P.G. Blackwell, C.E. Buck, T.F.G. Higham and P.J. Reimer, 2004. ISHCAL04 southern hemisphere calibration, 0 - 11.0 cal kyr BP. Radiocarbon, 46: 1087-92.

McFadgen, B.G., 1994. Archaeology and Holocene sand dune stratigraphy on Chatham Island. Journal of the Royal Society of New Zealand, 24: 17-44.

Park, G.S. 1976. The dendroglyphs and petroglyphs of the Chatham Islands: A report to the New Zealand Historic Places Trust. Working Papers in Chatham Island Archaeology, 3: 1-21.

Petchey, F., A. Anderson, A. Hogg and A. Zondervan, 2008. The marine reservoir effect in the Southern Ocean: An evaluation of extant and new $\Delta \mathrm{R}$ values and their application to archaeological chronologies. Journal of the Royal Society of New Zealand, 38 (4): 243-62.

Powell, A.W.B., 1979. New Zealand Mollusca. Auckland: Collins.

Reimer, P.J., M.G.L Baillie, E. Bard, A. Bayliss, J.W. Beck, P.G. Blackwell, C. Bronk Ramsey, C.E. Buck, G.S. Burr, R.L. Edwards, M. Friedrich, P.M. Grootes, T.P. Guilderson, I. Hajdas, T.J. Heaton, A.G. Hogg, K.A. Hughen, K.F. Kaiser, B. Kromer, F.G. McCormac, S.W. Manning, R.W. Reimer, D.A. Richards, J.R. Southon, S. Talamo, C.S. M. Turney, J. van der Plicht and C.E. Weyhenmeyer, 2009. IntCal09 and marine09 radiocarbon age calibration curves, $0-50,000$ years cal BP. Radiocarbon, 51 (4): 1111-50.

Richards, R., 2007. Manu Moriori: Human and Bird Carvings on Live Kopi trees on the Chatham Islands. Wellington: Paramata Press.

Schmidt, M.D., 2000. Radiocarbon Dating New Zealand Prehistory Using Marine Shell. Oxford: BAR International Series 842.

Simmons, D.R., 1965. A preliminary report on an associated group of dendroglyphs in the Chatham Islands. New Zealand Archaeological Association Newsletter, 8 (2): $39-43$

1980. Some dendroglyph styles in the Chatham Islands. Records of the Auckland Institute and Museum, 17: 49-63.

Skinner, H.D., 1923. The Morioris of Chatham Islands. Bernice P. Bishop Museum Memoirs 9 (1). Honolulu: Bishop Museum.

Skinner, H.D. and W. Baucke, 1928. The Morioris. Bernice P. Bishop Museum Memoirs 9 (5). Honolulu: Bishop Museum. 
Solomon, M. and S. Forbes, 2010. Indigenous archaeology: A Moriori case study. In C. Phillips and H. Allen (eds), Bridging the Divide: Indigenous Communities and Archaeology into the 21st Century. One World Archaeology 60. Walnut Creek, CA: Left Coast Press, pp. 213-32.

Wilmshurst, J., T.L. Hunt, C.P. Lipo, and A.J. Anderson, 2011. High precision radiocarbon dating shows recent and rapid initial human coloniation of East Polynesia. PNAS, 108: 1815-20.

\begin{abstract}
Images indented into living kōpi (Corynocarpus laevigatus) trees by Polynesian Moriori of the Chatham Islands are a novel, indigenous Oceanic carving expression. Currently the absolute chronology of the kōpi tree carving (räkau momori) tradition is poorly resolved. In a recent Rēkohu (Chatham Island) investigation, two isolated shell midden sites were recorded and excavated in the vicinity of rākau momori clusters. A cultural landscape assessment provides reasonable cause to identify each carved tree cluster and midden association as discrete social space. Radiocarbon dates on paired marine shellfish samples of different taxa from the Kaingaroa Station Covenant midden and on paired marine and terrestrial kōpi seed samples from the Taia Bush Historic Reserve midden are reported. At the least these dates identify probable, pre19th century Moriori use of $k \bar{p} p \bar{\imath}$ forest. On site context grounds we suggest that these dates may represent a terminus ante quem for the tree carving tradition as well.
\end{abstract}

Keywords: Moriori tree carvings, middens, social space, radiocarbon dates 